\title{
Degradation of host protease inhibitors and activation of plasminogen by proteolytic enzymes from Porphyromonas gingivalis and Treponema denticola
}

\author{
Daniel Grenier
}

Tel: +1 418656 7341. Fax: +1418656 2861. e-mail: Daniel.Grenier@greb.ulaval.ca

Groupe de Recherche en Ecologie Buccale, Faculté de Médecine Dentaire, Université Laval, SainteFoy, Québec, Canada G1K 7P4

\begin{abstract}
Bacterial proteases may participate in the pathogenesis of periodontal diseases through their action on host proteins. In the present study, the ability of selected periodontopathogens, as well as two proteases isolated from Porphyromonas gingivalis and Treponema denticola, to degrade host protease inhibitors was evaluated. The activation of human plasminogen by the two bacterial proteases was also investigated. Proteolytic breakdown of host protease inhibitors ( $\alpha$-1-antitrypsin, antichymotrypsin, $\alpha_{2}$-macroglobulin, antithrombin III, antiplasmin and cystatin C) was evaluated by SDS-PAGE. The $80 \mathrm{kDa}$ trypsin-like protease of $P$. gingivalis completely digested the six protease inhibitors under investigation, whereas the 95 kDa chymotrypsin-like protease of $T$. denticola was slightly less active, more particularly on $\alpha_{2}$ macroglobulin and cystatin $\mathrm{C}$. When whole cells from a number of oral bacterial species were tested, the most significant degradation was obtained with P. gingivalis, $T$. denticola, Prevotella intermedia, Prevotella nigrescens and Capnocytophaga spp. Peptostreptococcus micros and Propionibacterium acnes had only some degradative activity on selected inhibitors, whereas three bacterial species, Actinobacillus actinomycetemcomitans, Bacteroides forsythus and Fusobacterium nucleatum, had no effect on the protease inhibitors. The $80 \mathrm{kDa}$ protease of $P$. gingivalis demonstrated strong plasminogen activation, whereas no such activity was associated with the $95 \mathrm{kDa}$ protease of $T$. denticola. This study indicates the high potential of some periodontal pathogens to destroy protease inhibitors and activate plasminogen. This may result in an uncontrolled degradation of periodontal tissues and a rapid progression of the disease.
\end{abstract}

Keywords: Porphyromonas gingivalis, Treponema denticola, bacterial proteases, plasma protease inhibitors, periodontal disease

\section{INTRODUCTION}

Periodontal diseases are probably the most common chronic inflammatory disorder in adults and often lead to tooth loss (Williams, 1990). Among over 300 bacterial species found in the oral cavity, only some, either alone or in combination, are thought to participate in the pathogenic process of periodontal diseases (Haffajee \& Socransky, 1994). Although there is no doubt that bacteria represent the primary factor in the aetiology of periodontitis, the tissue destruction is also a consequence of the host response (Seymour et al., 1993). The fact that a significant reduction in gingival collagen fibre density is associated with the appearance of adult periodontitis (From \& Schultz-Haudt, 1963) suggests that proteases from host cells and periodontopathogens such as Porphyromonas gingivalis and Treponema denticola, may play a critical role in the disease.

Over the last ten years, increasing numbers of reports have underlined the potential importance of bacterial proteases, more particularly from $P$. gingivalis and $T$. denticola, in the pathogenesis of periodontal diseases (Grenier \& Mayrand, 1993; Holt \& Bramanti, 1991). Some evidence for the presence of bacterial proteases in vivo is also available. For example, on the basis of analyses 


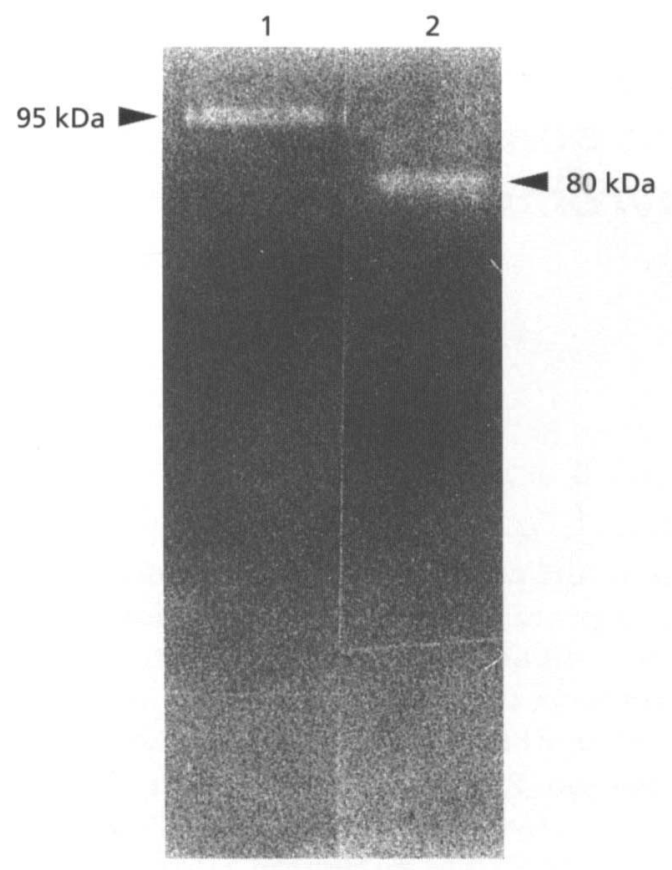

Fig. 1. Detection of proteolytic activity by zymography. Protease preparations were separated by electrophoresis on a BSA-conjugated SDS-PAGE gel. The gel was then washed, incubated and stained as described in Methods. Lanes: 1, $95 \mathrm{kDa}$ protease from $T$. denticola; $2,80 \mathrm{kDa}$ protease from $P$. gingivalis.

of serum IgG responses in periodontitis patients, it has been suggested that $P$. gingivalis proteases are important antigens (Ismail et al., 1988). Furthermore, a positive correlation was demonstrated between trypsin-like activity in subgingival sites and both the level of clinical disease and the numbers of $P$. gingivalis and spirochaetes (Suido et al., 1988).

Previous studies have indicated that $P$. gingivalis and $T$. denticola are capable of degrading basement membrane components, such as collagen and fibronectin (Grenier \& Mayrand, 1993; Grenier et al., 1990; Holt \& Bramanti, 1991), suggesting a direct role for these bacteria in degradation and invasion of periodontal tissues. Bacterial proteases may also participate indirectly in tissue destruction. It is well known that plasma protease inhibitors may contribute to host defences by inhibiting bacteriaand host-derived proteolytic activities. In the gingival crevicular fluid, their presence may help preserve the integrity of the periodontal tissues. The degradation of $\alpha$ 1 -antitrypsin and $\alpha_{2}$-macroglobulin by cells of $P$. gingivalis and $T$. denticola has been previously demonstrated (Carlsson et al., 1984; Fishburn et al., 1991; Herrmann et al., 1985; Uitto et al., 1988). C1-inhibitor, $\alpha_{2}$-antiplasmin and antithrombin, which are involved in the control of the plasma proteinase cascade system, are also degraded by $P$. gingivalis (Nilsson et al., 1985). It is suggested that inactivation of these inhibitors may enhance inflammatory responses, vascular permeability and fibrinolysis, thus contributing to the pathogenic process of periodontal disease. Plasmin activity was previously reported to increase in gingival fluid from affected periodontal sites (Hidaka et al., 1981). The ability of proteases from bacteria to activate human plasminogen into plasmin may represent an additional mechanism by which these bacterial enzymes indirectly participate in tissue destruction.

In the present study, the ability of selected periodontopathogens, as well as two proteases isolated from $P$. gingivalis and $T$. denticola, to degrade host protease inhibitors was evaluated. The activation of human plasminogen by the two bacterial proteases was also investigated.

\section{METHODS}

Bacteria and growth conditions. The reference and clinical strains of oral bacterial species under investigation were: Actinobacillus actinomycetemcomitans ATCC 29522 and Y4, Bacteroides forsythus ATCC 43037 and 4067M27, Capnocytophaga spp. VA and III.21, Fusobacterium nucleatum 102.3 and CM33MB-5, Peptostreptococcus micros NY370 and 89A, P. gingivalis ATCC 33277 and W50, Prevotella intermedia ATCC 25611 and NY365, Prevotella nigrescens NCTC 9336 and SPRO2, Propionibacterium acnes T1 and UD, T. denticola A TCC 35405 and $\mathrm{e}^{\prime}$. Except for $T$. denticola and $B$. forsythus, all bacteria were grown in Todd Hewitt broth (BBL Microbiology Systems) supplemented with haemin $\left(10 \mu \mathrm{g} \mathrm{ml}^{-1}\right)$ and vitamin $\mathrm{K}\left(1 \mu \mathrm{g} \mathrm{ml}^{-1}\right)$. T. denticola was cultured in the oral spirochaete medium as previously described by Leschine \& Canale-Parola (1980), whereas B. forsythus was grown in Todd Hewitt broth supplemented with $5 \%(\mathrm{v} / \mathrm{v})$ heat-inactivated calf serum and $0.001 \%(\mathrm{w} / \mathrm{v}) \mathrm{N}$-acetylmuramic acid. The cultures were incubated in an anaerobic chamber $\left[\mathrm{N}_{2} / \mathrm{H}_{2} / \mathrm{CO}_{2}(80: 10: 10\right.$, by vol.) $]$ at $37^{\circ} \mathrm{C}$ to late exponential growth phase.

Isolation of bacterial proteases. Proteases from $P$. gingivalis and $T$. denticola were isolated by preparative PAGE according to a procedure previously described by Grenier (1992) and Uitto et al. (1988), respectively. A preparation of outer-membrane vesicles (Singh et al., 1989) was used as starting material for the isolation of the $80 \mathrm{kDa}$ protease from $P$. gingivalis. The $95 \mathrm{kDa}$ protease from $T$. denticola was isolated from a sonicated cell extract (five times for $45 \mathrm{~s}, 30 \%$ duty cycle, output 5; Sonifier Cell Disrupter, Branson Sonic Power). The final protease preparations were adjusted to 35 and $60 \mu \mathrm{g}$ protein $\mathrm{ml}^{-1}$ for $P$. gingivalis and $T$. denticola, respectively. Protein was quantified by using a Bio-Rad microassay with BSA as the standard. The presence of only one proteolytic enzyme in the final preparations was verified by SDS-PAGE incorporating covalently bound BSA (Grenier et al., 1989). After electrophoresis, the gel was shaken in $0 \cdot 1 \mathrm{M}$ Tris $/ \mathrm{HCl}, \mathrm{pH} 7 \cdot 2$, containing $2 \%(\mathrm{v} / \mathrm{v})$ Triton $\mathrm{X}-100$, followed by a wash in $0 \cdot 1 \mathrm{M}$ Tris/ $\mathrm{HCl}$ to remove the detergents. The gel was then incubated at $37^{\circ} \mathrm{C}$ for $2 \mathrm{~h}$ in $0.1 \mathrm{M}$ Tris $/ \mathrm{HCl}, \mathrm{pH} 7 \cdot 2$, supplemented with $10 \mathrm{mM} \mathrm{DTT}$ to allow the enzymic degradation of the conjugated protein substrate. The gel was then stained for proteins with Coomassie brilliant blue. Following destaining of the gel, the presence of a proteolytic activity was visualized as a clear band against a blue background. The molecular mass markers were myosin $(200 \mathrm{kDa})$, phosphorylase b $(97 \cdot 4 \mathrm{kDa}), \mathrm{BSA}(69 \cdot 8 \mathrm{kDa})$, ovalbumin $(43 \mathrm{kDa})$ and carbonic anhydrase $(29 \mathrm{kDa})$.

Assay for degradation of host protease inhibitors. The degradation of $\alpha$-1-antitrypsin, antichymotrypsin, $\alpha_{2^{-}}$ macroglobulin, antithrombin III, antiplasmin and cystatin $C$ by 
(a)

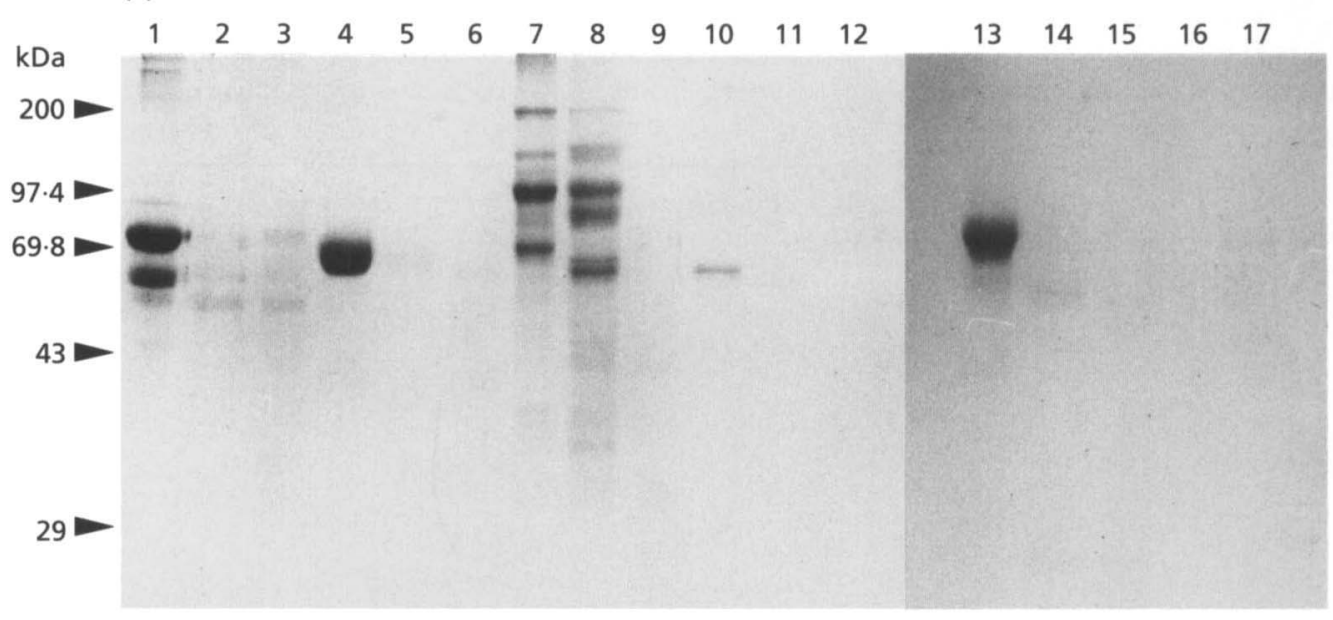

(b)

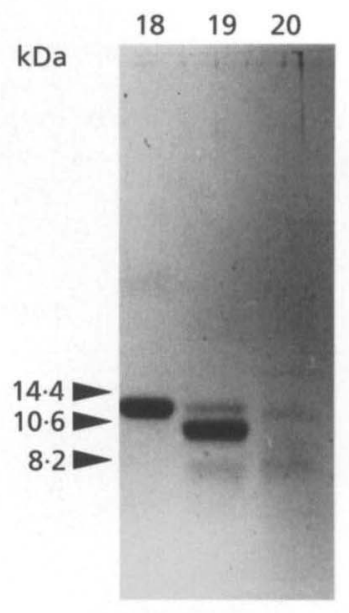

Fig. 2. Degradation of host protease inhibitors by the protease preparations. Inhibitors were incubated with the purified proteases $\left(37^{\circ} \mathrm{C}\right.$ for $\left.16 \mathrm{~h}\right)$, and the assay mixtures were boiled and analysed by SDS-PAGE. Lanes: $1-3, \alpha-1$-antitrypsin; 4-6, antichymotrypsin; 7-9, $\alpha_{2}$-macroglobulin; 10-12, antithrombin III; 13-15, antiplasmin; 16-17, no inhibitor; 18-20, cystatin C. Assays in lanes $2,5,8,11,14,16$ and 19 were performed in the presence of the $95 \mathrm{kDa}$ protease from $T$. denticola. Assays in lanes $3,6,9,12,15,17$ and 20 were performed in the presence of the $80 \mathrm{kDa}$ protease from $P$. gingivalis. Molecular mass markers were (from top to bottom): myosin (200 kDa), phosphorylase b (97.4 kDa), BSA (69.8 kDa), ovalbumin (43 kDa) and carbonic anhydrase ( $29 \mathrm{kDa})$ for gel (a) and myoglobin I and II (14.4 kDa), myoglobin I and III $(10.6 \mathrm{kDa})$ and myoglobin I $(8.2 \mathrm{kDa})$ for gel (b). The high molecular mass band in the $\alpha$-1-antitrypsin preparation is thought to represent transferrin contamination.

proteolytic enzymes and whole bacteria was determined by assaying for lower-molecular-mass degradation fragments by SDS-PAGE $(11 \%, \mathrm{w} / \mathrm{v}$, gel; $15 \%$ in the case of cystatin C) using the buffer system of Laemmli (1970). Briefly, $10 \mu$ l protease preparations or bacterial cells $\left(\mathrm{OD}_{660}=2.0\right.$ in $50 \mathrm{mM}$ Tris $/ \mathrm{HCl}$, $\mathrm{pH} 7 \cdot 2$ ) was incubated at $37^{\circ} \mathrm{C}$ with $10 \mu$ l protease inhibitor $\left(1 \mathrm{mg} \mathrm{ml}^{-1}\right)$ and with $20 \mu \mathrm{l} 50 \mathrm{mM}$ Tris/ $\mathrm{HCl}, \mathrm{pH} 7 \cdot 2$, containing $10 \mathrm{mM}$ DTT. At the end of the incubation period $(16 \mathrm{~h}$ for the protease preparations and $8 \mathrm{~h}$ for bacterial cells), cells were removed by centrifugation and $10 \mu \mathrm{l}$ SDS sample buffer $(0.125 \mathrm{M}$ Tris/HCl, $\mathrm{pH} 6.8 ; 2 \%, \mathrm{w} / \mathrm{v}, \mathrm{SDS} ; 2 \%, \mathrm{w} / \mathrm{v}$, mercaptoethanol; $20 \%, \mathrm{v} / \mathrm{v}$, glycerol; $0.01 \%$, w/v, bromophenol blue) was added prior to boiling for $10 \mathrm{~min}$. Samples were then run on SDS-PAGE gels and proteins were stained with Coomassie brilliant blue.

Assay for plasminogen activator activity. Plasminogen activation was measured by mixing $20 \mu$ serial dilutions $(1: 2)$ of the protease preparations with an equal volume of human plasminogen $\left(2 \mathrm{mg} \mathrm{ml}^{-1}\right)$ and with $30 \mu \mathrm{l} 50 \mathrm{mM}$ Tris/ $\mathrm{HCl}, \mathrm{pH}$ 7.2. The human plasminogen and buffer were prereduced by an overnight incubation in the anaerobic chamber. The reaction mixtures were incubated anaerobically at $37^{\circ} \mathrm{C}$ for $2 \mathrm{~h}$. Thereafter, $15 \mu \mathrm{l}$ Val-Leu-Lys- $p$-nitroanilide $\left(2 \mathrm{mg} \mathrm{ml}^{-1}\right)$, a chromogenic substrate for human plasmin (Kulisek et al., 1989), was added and the mixture was further incubated at $37^{\circ} \mathrm{C}$ for $2 \mathrm{~h}$ prior to measuring the $A_{405}$ with a microtitre plate ELISA reader (SLT-Labinstruments). Boiling the protease preparations or the omission of human plasminogen in the assay were used as controls. The assay was also carried out using streptokinase, a known plasminogen activator produced by most group $\mathrm{A}, \mathrm{C}$ and $G$ streptococci (Huang et al., 1989). Following incubation of plasminogen with the protease preparations, a sample was obtained and analysed by SDS-PAGE (11\% gel). The gel was stained for proteins using Coomassie brilliant blue.

\section{RESULTS}

\section{Preparation of bacterial proteases}

On an SDS-PAGE gel containing covalently bound BSA, a single proteolytic band was found in the final protease preparations (Fig. 1). The molecular mass of the $P$. gingivalis and $T$. denticola proteases was estimated to be $80 \mathrm{kDa}$ (lane 2) and $95 \mathrm{kDa}$ (lane 1), respectively. Using synthetic chromogenic peptides and specific protease inhibitors (data not shown), the proteases were found to have properties corresponding to those previously reported in the original studies (Grenier, 1992; Uitto et al., 1988). The $80 \mathrm{kDa}$ enzyme from $P$. gingivalis was a thiolactivated trypsin-like protease, whereas the $95 \mathrm{kDa}$ enzyme from $T$. denticola was a thiol-activated chymotrypsinlike protease.

\section{Degradation of protease inhibitors}

Proteolytic breakdown of protease inhibitors by the two bacterial proteases was evaluated by SDS-PAGE (Fig. 2). The $80 \mathrm{kDa}$ trypsin-like protease of $P$. gingivalis completely digested the six protease inhibitors under investigation (lanes 3, 6, 9, 12, 15 and 20). On the other hand, the $95 \mathrm{kDa}$ chymotrypsin-like protease of $T$. denticola was found to degrade extensively $\alpha$-1-antitrypsin (lane 2), antichymotrypsin (lane 5), antithrombin III (lane 11) and antiplasmin (lane 14). The protein band corresponding to the subunit of $\alpha_{2}$-macroglobulin was only slightly decreased (lane 8). Finally, the $T$. denticola protease degraded 
Table 1. Degradation of host protease inhibitors by periodontopathogens

Degradation was determined by SDS-PAGE. - , No degradation of the protease inhibitor band; + , partial degradation of the protease inhibitor band; ++ , complete degradation of the protease inhibitor band; F, degradation with production of lower molecular mass fragments (number of fragments in parentheses).

Strain

Degradation

\begin{tabular}{|c|c|c|c|c|c|c|}
\hline & $\begin{array}{c}\alpha-1- \\
\text { Antitrypsin }\end{array}$ & Antichymotrypsin & $\alpha_{2}$-Macroglobulin & Antithrombin III & Antiplasmin & Cystatin C \\
\hline \multicolumn{7}{|c|}{ A. actinomycetemcomitans } \\
\hline ATCC 29522 & - & - & - & - & - & - \\
\hline Y4 & - & - & - & - & - & - \\
\hline \multicolumn{7}{|l|}{ B. forsythus } \\
\hline ATCC 43037 & - & - & - & - & - & - \\
\hline $4067 \mathrm{M} 27$ & - & - & - & - & - & - \\
\hline \multicolumn{7}{|c|}{ Capnocytophaga spp. } \\
\hline VA & - & $\mathrm{F}(1)$ & + & $\mathrm{F}(1)$ & $\mathrm{F}(3)$ & + \\
\hline III.21 & - & $F(3)$ & + & $\mathrm{F}(2)$ & $\mathrm{F}(3)$ & $\mathrm{F}(1)$ \\
\hline \multicolumn{7}{|l|}{ F. nucleatum } \\
\hline 102.3 & - & - & - & - & - & - \\
\hline CM33MB-5 & - & - & - & - & - & - \\
\hline \multicolumn{7}{|l|}{ Pept. micros } \\
\hline NY370 & - & - & + & - & - & + \\
\hline $89 \mathrm{~A}$ & - & - & + & - & - & + \\
\hline \multicolumn{7}{|l|}{ P. gingivalis } \\
\hline ATCC 33277 & ++ & $\mathrm{F}(1)$ & ++ & ++ & ++ & ++ \\
\hline W50 & ++ & $F(1)$ & ++ & ++ & ++ & ++ \\
\hline \multicolumn{7}{|c|}{ Prev. intermedia } \\
\hline ATCC 25611 & + & + & + & $+t$ & + & - \\
\hline NY365 & - & - & + & + & + & + \\
\hline \multicolumn{7}{|c|}{ Prev. nigrescens } \\
\hline NCTC 9336 & + & + & + & + & $\mathrm{F}(2)$ & + \\
\hline SPRO 2 & - & + & + & + & + & + \\
\hline \multicolumn{7}{|l|}{ Prop. acnes } \\
\hline $\mathrm{T} 1$ & - & - & - & + & - & $\mathrm{F}(1)$ \\
\hline UD & - & - & - & + & - & - \\
\hline \multicolumn{7}{|l|}{ T. denticola } \\
\hline ATCC 35405 & - & $F(1)$ & + & ++ & $\mathrm{F}(2)$ & + \\
\hline $\mathrm{e}^{\prime}$ & - & + & + & + & $\mathrm{F}(2)$ & + \\
\hline
\end{tabular}

cystatin $\mathrm{C}$ with the production of one major fragment of less than $10 \mathrm{kDa}$ (lane 19).

To investigate if other suspected periodontopathogens had the ability to degrade host protease inhibitors, similar assays of digestion were carried out using whole bacteria (Table 1). The most active bacteria were $P$. gingivalis, $T$. denticola, Prev. intermedia, Prev. nigrescens and Capnocytophaga spp. Pept. micros and Prop. acnes had only some degradative activity towards selected inhibitors. The complete disappearance of an inhibitor is related to a proteolytic degradation rather than to a binding to bacterial cells. This is indicated by the fact that no degradation was observed when heat-treated cells were used or when a cocktail of low molecular mass protease inhibitors was added to the assay mixtures (data not shown). Three bacterial species, $A$. actinomycetemcomitans, $B$. forsytbus and $F$. nucleatum, had no effect on the host protease inhibitors tested.

\section{Plasminogen activator activity}

The ability of the protease preparations from $P$. gingivalis and $T$. denticola to activate human plasminogen is reported in Table 2. None of the proteases could degrade the plasmin substrate Val-Leu-Lys- $p$-nitroanilide. The $80 \mathrm{kDa}$ protease of $P$. gingivalis demonstrated strong plasminogen activation, whereas no such activity was associated with the $95 \mathrm{kDa}$ protease of $T$. denticola. Under the experimental conditions of the assay, the plasminogen activator activity found in the $P$. gingivalis protease 
Table 2. Plasminogen activator activity of the $80 \mathrm{kDa}$ trypsin-like protease from $P$. gingivalis and the $95 \mathrm{kDa}$ chymotrypsin-like protease from $T$. denticola

\begin{tabular}{|lcc|}
\hline $\begin{array}{l}\text { Enzyme (dilution } \\
\text { or amount) }\end{array}$ & \multicolumn{2}{c|}{$\begin{array}{c}\text { Hydrolysis of plasmin } \\
\text { substrate }\left(\boldsymbol{A}_{\mathbf{4 0 5}}\right)\end{array}$} \\
\cline { 2 - 3 } & $\begin{array}{c}\text { With } \\
\text { plasminogen }\end{array}$ & $\begin{array}{c}\text { Without } \\
\text { plasminogen }\end{array}$ \\
\hline $\boldsymbol{P}$ gingivalis protease $\mathbf{( 8 0} \mathbf{~ k D a )}$ & \\
$1: 2$ & 1.22 & 0.09 \\
$1: 4$ & 1.19 & 0.04 \\
$1: 8$ & 0.94 & 0.03 \\
T. denticola protease $\mathbf{( 9 5} \mathbf{~ k D a )}$ & \\
$1: 2$ & 0.09 & 0.04 \\
$1: 4$ & 0.07 & 0.03 \\
$1: 8$ & 0.08 & 0.03 \\
Streptokinase & & \\
0.1 unit & 1.31 & 0.04 \\
0.05 unit & 0.71 & 0.08 \\
0.025 unit & 0.29 & 0.03 \\
0.0125 unit & 0.16 & 0.03 \\
\hline
\end{tabular}

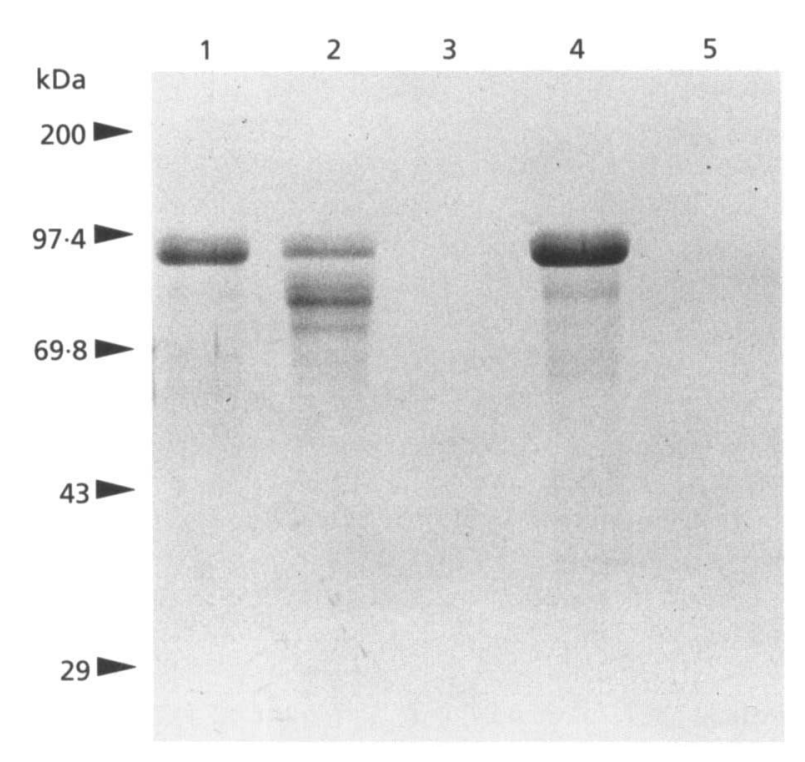

Fig. 3. Degradation of human plasminogen by the protease preparations. Plasminogen was incubated with the purified proteases $\left(37^{\circ} \mathrm{C}\right.$ for $\left.2 \mathrm{~h}\right)$, and the assay mixtures were boiled and analysed by SDS-PAGE. Lanes: 1, plasminogen alone; 2 , plasminogen plus the $80 \mathrm{kDa}$ protease from $P$. gingivalis; 3 , $80 \mathrm{kDa}$ protease from $P$. gingivalis alone; 4 , plasminogen plus the $95 \mathrm{kDa}$ protease from $T$. denticola; $5,95 \mathrm{kDa}$ protease from $T$. denticola alone. Molecular mass markers were (from top to bottom): myosin (200 kDa), phosphorylase b $(97.4 \mathrm{kDa})$, BSA $(69.8 \mathrm{kDa})$, ovalbumin $(43 \mathrm{kDa})$ and carbonic anhydrase (29 kDa).

preparation corresponded to 28 units streptokinase $\mathrm{ml}^{-1}$. SDS-PAGE analysis of the assay mixture showed that the $P$. gingivalis protease produced a number of fragments from plasminogen, including one with a molecular mass of $80 \mathrm{kDa}$ which may represent the active form of plasmin (Fig. 3, lane 2).

\section{DISCUSSION}

The development of periodontal diseases is associated with an increased level of proteolytic activity in subgingival sites, including the gingival crevicular fluid (Eley \& Cox, 1992; Sandholm, 1986). These enzymes, which originate from both the host and periodontopathogens, may participate in the pathogenesis of periodontal diseases through their action on host proteins. Several investigators have suggested that bacterial proteases may play a critical role in the development of periodontal diseases (Grenier \& Mayrand, 1993; Holt \& Bramanti, 1991). Since significant tissue damage is observed in periodontitis patients, it is thought that bacterial proteases may be, at least in part, responsible for this destruction. The fact that a significantly higher number of proteolytic bacteria was recently demonstrated in patients with periodontitis than in healthy patients reinforced this hypothesis (Grenier \& Turgeon, 1994).

The direct destructive effect by $P$. gingivalis may involve collagenolytic enzymes previously characterized (Grenier \& Mayrand, 1993). In the case of $T$. denticola, the $95 \mathrm{kDa}$ chymotrypsin-like protease used in this study was reported to represent an important determinant in invasion of a basement membrane model (Grenier et al., 1990). The indirect destructive effect by bacterial proteases may involve the digestion of host protease inhibitors. Plasma protease inhibitors present in gingival crevicular fluid as well as cystatin $\mathrm{C}$, a tissue protease inhibitor present in inflamed gingiva, may play a critical role in the protection of periodontal tissues by modulating protease activity, more particularly during active phases. Indeed, protease inhibitors are involved in the regulation of various proteolytic cascade systems, such as the complement system, the kallikrein-kinin system and the fibrinolytic and clotting system, as well as inflammatory reactions. As this study demonstrated that most of these host protease inhibitors were susceptible to degradation by bacterial proteases, their protective effect may be reduced. Interestingly, the amount of plasma protease inhibitors and cystatin $\mathrm{C}$ was reported to decrease significantly with the progression of the disease (Lah et al., 1993). This may result in an uncontrolled degradation of periodontal tissues and a rapid progression of the disease.

The ability of periodontopathic bacteria, more particularly $P$. gingivalis and $T$. denticola, to degrade and inactivate plasma protease inhibitors has been previously reported (Carlsson et al., 1984; Fishburn et al., 1991; Herrmann et al., 1985; Nilsson et al., 1985; Uitto et al., 1988). As whole bacterial cells were used in most studies, the nature of proteases involved in the degradation was not identified. This report extends our knowledge by indicating that two cell-associated proteases, a trypsin-like protease $(80 \mathrm{kDa})$ from $P$. gingivalis and a chymotrypsin-like protease $(95 \mathrm{kDa})$ from $T$. denticola, may be, at least in part, responsible for the degradation. The most active 
enzyme was found to be the $80 \mathrm{kDa}$ protease from $P$. gingivalis, which completely degraded the six host protease inhibitors under investigation. Fishburn et al. (1991) previously reported that extracellular trypsin-like activity produced by $P$. gingivalis could hydrolyse the major serum proteins and could be inhibited by the serine protease inhibitor antithrombin III. In the present study, it was shown that the cell-associated $80 \mathrm{kDa}$ trypsin-like protease of $P$. gingivalis completely digested antithrombin III.

A $35 \mathrm{kDa}$ protease from $P$. gingivalis was previously found to stimulate fibroblasts to secrete plasminogen activator (Uitto et al., 1989). Here, it is demonstrated that the $80 \mathrm{kDa}$ protease from $P$. gingivalis activates human plasmin, a serine protease with trypsin-like activity. The fact that the $80 \mathrm{kDa}$ protease of $P$. gingivalis does not degrade the plasmin substrate in the plasminogen activation assay indicates that it is a trypsin-like enzyme unable to cleave at bonds involving lysine residues. The active plasmin, if generated at subgingival sites, may be potentially deleterious as it is capable of activating the kinin cascade and is strongly implicated in the inflammatory process. It may also catalyse proteolytic cleavages in inactive zymogens of matrix metalloproteinases, leading to active enzymes (Mignatti et al., 1986). Previous studies also indicated that a proteolytic fraction from $P$. gingivalis is able to activate latent matrix metalloproteinases (Birkedal-Hansen $e t$ al., 1984) and induce their secretion by human gingival fibroblasts (Uitto et al., 1989).

Additional pathogenic roles have been ascribed to the $80 \mathrm{kDa}$ protease from $P$. gingivalis. This protease can inactivate the bactericidal activity of human serum, thus protecting susceptible bacteria found in periodontal pockets (Grenier, 1992). The $80 \mathrm{kDa}$ protease can also generate $\mathrm{Fc}$ fragments from human IgG1 which can stimulate a marked increase in the release of interleukin-6, interleukin-8, and tumour necrosis factor alpha from human peripheral blood mononuclear cells and thus shows that this enzyme may contribute to the inflammatory process in periodontitis (Engel et al., 1994).

In summary, this study is in agreement with the model of pathogenesis of periodontal disease proposed by Travis $e t$ al. (1994). It was suggested that following an overg rowth of $P$. gingivalis, the bacteria secreted proteinases which could not be neutralized by protease inhibitors found in subgingival sites. These bacterial proteases activate the complement system, resulting in a migration of inflammatory cells at the infection site. The inability of phagocytic cells to destroy bacteria results in a chronic influx of inflammatory cells associated with an important release of host hydrolytic enzymes, including proteases. Altogether, the host and bacterial enzymes will severely damage the periodontal tissues.

\section{ACKNOWLEDGEMENTS}

This research was supported by the Medical Research Council of Canada. I wish to thank Denis Mayrand for helpful discussion and Josée Michaud for her excellent technical assistance.

\section{REFERENCES}

Birkedal-Hansen, H., Wells, B. R., Lin, H. Y., Caufield, P. W. \& Taylor, R. E. (1984). Activation of keratinocyte-mediated collagen (type I) breakdown by suspected human periodontopathogen. J Periodontal Res 19, 645-650.

Carlsson, J., Herrmann, B. F., Høfling, J. F. \& Sundqvist, G. K. (1984). Degradation of the human proteinase inhibitors alpha-1antitrypsin and alpha-2-macroglobulin by Bacteroides gingivalis. Infect Immun 43, 644-648.

Eley, B. M. \& Cox, S. W. (1992). Cathepsin B/L-, elastase-, tryptase-, trypsin- and dipeptidyl peptidase IV-like activities in gingival crevicular fluid: correlation with clinical parameters in untreated chronic periodontitis patients. J Periodontal Res 27, 62-69.

Engel, D., Grenier, D., Hobbs, M., Morgan, E., Hugli, T. E. \& Weigle, W. O. (1994). Inflammatory potential of IgG Fc fragments generated by Porphyromonas gingivalis protease. F ASEB J 8, 223.

Fishburn, C. S., Slaney, J. M., Carman, R. J. \& Curtis, M. A. (1991). Degradation of plasma proteins by the trypsin-like enzyme of Porphyromonas gingivalis and inhibition of protease activity by a serine protease inhibitor of human plasma. Oral Microbiol Immunol 6, 209-215.

From, S. \& Schultz-Haudt, S. D. (1963). Comparative histological and microchemical evaluations of the collagen content of human gingiva. J Periodontol 34, 216-223.

Grenier, D. (1992). Inactivation of human serum bactericidal activity by a trypsinlike protease isolated from Porpbyromonas gingivalis. Infect Immun 60, 1854-1857.

Grenier, D. \& Mayrand, D. (1993). Proteinases. In Biology of the species Porphyromonas gingivalis, pp. 227-243. Edited by H. N. Shah, D. Mayrand \& R. J. Genco. Boca Raton: CRC Press.

Grenier, D. \& Turgeon, J. (1994). Occurrence and identity of proteolytic bacteria in adult periodontitis. $J$ Periodontal Res 29, $365-370$.

Grenier, D., Chao, G. \& McBride, B. C. (1989). Characterization of sodium dodecyl sulfate-stable Bacteroides gingivalis proteases by polyacrylamide gel electrophoresis. Infect Immun 57, 95-99.

Grenier, D., Uitto, V.-J. \& McBride, B. C. (1990). Cellular location of a Treponema denticola chymotrypsinlike protease and importance of the protease in migration through the basement membrane. Infect Immun 58, 347-351.

Haffajee, A. D. \& Socransky, S. S. (1994). Microbial etiological agents of destructive periodontal diseases. Periodontology 2000 5, 78-111.

Herrmann, B. F., Carlsson, J. \& Sundqvist, G. K. (1985). Inactivation of guinea-pig serum proteinase inhibitors by Bacteroides gingivalis. Scand J Dent Res 93, 153-157.

Hidaka, N., Maeda, K., Kawakami, C., Aono, M. \& Okada, H. (1981). Fibrinolytic activity in periodontal disease. J Periodontol 52, 181-186.

Holt, S. C. \& Bramanti, T. E. (1991). Factors in virulence expression and their role in periodontal disease pathogenesis. Crit Rev Oral Biol Med 2, 177-281.

Huang, T.-T., Malke, H. \& Ferretti, J. J. (1989). Heterogeneity of the streptokinase gene in group A streptococci. Infect Immun 57, 502-506

Ismail, M. O., Greenman, J. \& Scully, C. (1988). Serum antibodies against the trypsin-like protease of Bacteroides gingivalis in periodontitis. J Periodontal Res 23, 193-198.

Kulisek, E. S., Holm, S. E. \& Johnston, K. H. (1989). A chromogenic assay for the detection of plasmin generated by plasminogen 
activator immobilized on nitrocellulose using a para-nitroanilide synthetic peptide substrate. Anal Biochem 177, 78-84.

Laemmli, U. K. (1970). Cleavage of structural proteins during the assembly of the head of bacteriophage T4. Nature 227, 680-685.

Lah, T. T., Babnik, J., Schiffmann, E., Turk, V. \& Skaleric, U. (1993). Cysteine proteinases and inhibitors in inflammation: their role in periodontal disease. J Periodontol 64, 485-491.

Leschine, S. B. \& Canale-Parola, E. (1980). Rifampin as a selective agent for isolation of oral spirochetes. J Clin Microbiol 12, 792-795.

Mignatti, P., Robbins, E. \& Rifkin, D. B. (1986). Tumor invasion through the human amniotic membrane: requirement for a proteinase cascade. Cell 47, 487-498.

Nilsson, T., Carlsson, J. \& Sundqvist, G. (1985). Inactivation of key factors of the plasma proteinase cascade systems by Bacteroides gingivalis. Infect Immun 50, 467-471.

Sandholm, L. (1986). Proteases and their inhibitors in chronic inflammatory periodontal disease. J Clin Periodontol 13, 19-26.

Seymour, G. J., Gemmell, E., Reinhardt, R. A., Eastcott, J. W. \& Taubman, M. A. (1993). Immunopathogenesis of chronic inflammatory periodontal disease: cellular and molecular mechanisms. $J$ Periodontal Res 28, 478-486.
Singh, U., Grenier, D. \& McBride, B. C. (1989). Bacteroides gingivalis vesicles mediate attachment of streptococci to serum-coated hydroxyapatite. Oral Microbiol Immunol 4, 199-203.

Suido, H., Zambon, J. J., Mashimo, P. A., Dunford, R. \& Genco, R. J. (1988). Correlations between gingival crevicular fluid enzymes and the subgingival microflora. J Dent Res 67, 1070-1080.

Travis, J., Pike, R., Imamura, T. \& Potemba, J. (1994). The role of proteolytic enzymes in the development of pulmonary emphysema and periodontal disease. Am J Respir Crit Care Med 150, S143-146.

Uitto, V.-J., Grenier, D., Chan, E. C. S. \& McBride, B. C. (1988). Isolation of a chymotrypsinlike enzyme from Treponema denticola. Infect Immun 56, 2717-2722.

Uitto, V.-J., Larjava, H., Heino, J. \& Sorsa, T. (1989). A protease of Bacteroides gingivalis degrades cell surface and matrix glycoproteins of cultured gingival fibroblasts and induces secretion of collagenase and plasminogen activator. Infect Immun 57, 213-218.

Williams, R. C. (1990). Periodontal disease. New Engl J Med 322, 373-382.

Received 5 September 1995; revised 14 November 1995; accepted 28 November 1995. 